\title{
The geometric evolution of structures in granite during continous deformation from magmatic to solid-state conditions: An example from the central European Variscan Belt
}

\author{
STEFFEN H. BÜTTNER
}

\author{
Institut für Angewandte Geowissenschaften, Technische Universität Berlin \\ Strasse des 17. Juni 135, D-10623 Berlin, Germany
}

\begin{abstract}
Intrusive and in-situ granites of the late-Variscan South Bohemian batholith (Austria) were deformed continuously during crystallization and after solidification by horizontal crustal shortening. When the proportion of melt was relatively high, the granitic magmas accomodated deformation in (low-angle) thrust zones. With decreasing melt content shearing became more localized and the dip angle of shear planes increased during the formation of submagmatic reverse shear zones. During this submagmatic stage the orientation of shear planes was variable. They probably rotated from flat in the magmatic stage to a steeper orientation perpendicular to the shortening direction and/or parallel to post-magmatic conjugated strike-slip zones, that became active at high- $T$, solid state conditions. Thermobarometry and the compositions of plagioclase phenocrysts, subgrains, and recrystallized grains indicate that the magmatic, submagmatic, and high- $T$, solid state strike-slip deformation occurred at similar $P$ - $T$ conditions. Conjugate strike-slip zones are well known structures of solid-state crustal shortening. In syn-tectonic plutons, they may have magmatic or submagmatic precursors, and because they preferably crosscut the plutons rather than the country rock, this could be the result of earlier magmatic or submagmatic deformation, that evolves to solid state shear zones. Hot (migmatitic) crust during magma emplacement, coupled with low cooling rates and a constant direction of crustal shortening probably aids the generation and preservation of related magmatic, submagmatic, and postmagmatic structures.
\end{abstract}

\section{INTRODUCTION}

This paper describes the structural evolution of syntectonic granites during intrusion and in-situ melting, solidification, and mylonitization at high temperature under bulk horizontal crustal shortening. It illustrates the effects of changes in rheological behavior of a syntectonically crystallizing granite on structures at different scales, and how these structures can be identified. Furthermore, geological conditions that may favor the preservation of these structures are outlined. Deformation of magma is common in syntectonic plutons and has been described in numerous papers (e.g., Hutton 1988a, 1988b; Benn and Allard 1989; Hutton and Reavy 1992; Nicolas 1992; Paterson and Fowler 1993; Pitcher 1993; Davidson et al. 1996; Paterson and Miller 1998). Most of these studies describe the influence of regional tectonics on the ascent and emplacement of magma, and on structures generated at the magmatic or submagmatic stage. However, the geometric evolution of structures during the transition from magmatic flow to submagmatic and solidstate deformation is poorly understood and has been described only in a few studies (e.g., Gapais and Barbarin 1986; Blumenfeld and Bouchez 1988; Miller and Paterson 1994). Following a brief description of the regional geology, this pa-

\footnotetext{
*E-mail: Steffen.Buettner@TU-Berlin.de
}

per contains: (1) the description of structures and microfabrics in granites considered to form under magmatic, submagmatic, and solid-state conditions; (2) the geometric relationships among these structures; (3) thermobarometry in support of the temperature estimation from microstructural evidence; and (4) a discussion of the progressive geometric evolution of structures from magmatic flow to solid-state mylonitization in granitic batholiths.

\section{GEOLOGICAL SETTING}

Part of the central European Variscan belt was affected by late-Variscan ( 335-320 Ma) high-T/low- $P$ regional metamorphism that caused major anatexis in the middle crust. This metamorphic episode occurred as a consequence of gravitational collapse and isostatic readjustment of crust, which was thickened by the continent collision of Gondwana with Laurasia during Visean time (Büttner and Kruhl 1997). In the southern Bohemian Massif (Fig. 1), granitoid plutonism continued from the Upper Visean ( $\sim 330 \mathrm{Ma})$ till Permo-Carboniferous time ( 300 Ma; Friedl et al. 1992, 1993, 1996), and formed the South Bohemian Batholith. In deeper levels of the batholith $(\sim 15 \mathrm{~km})$, such as exposed in the Mühlzone of Austria (Fig. 1), the crust was still under high- $T /$ low- $P$ conditions when the first plutons intruded. These late-orogenic granites supplied additional heat and fluids, which led to large scale in-situ melting of the country rock during granite emplacement (Finger and Clemens 1995). 


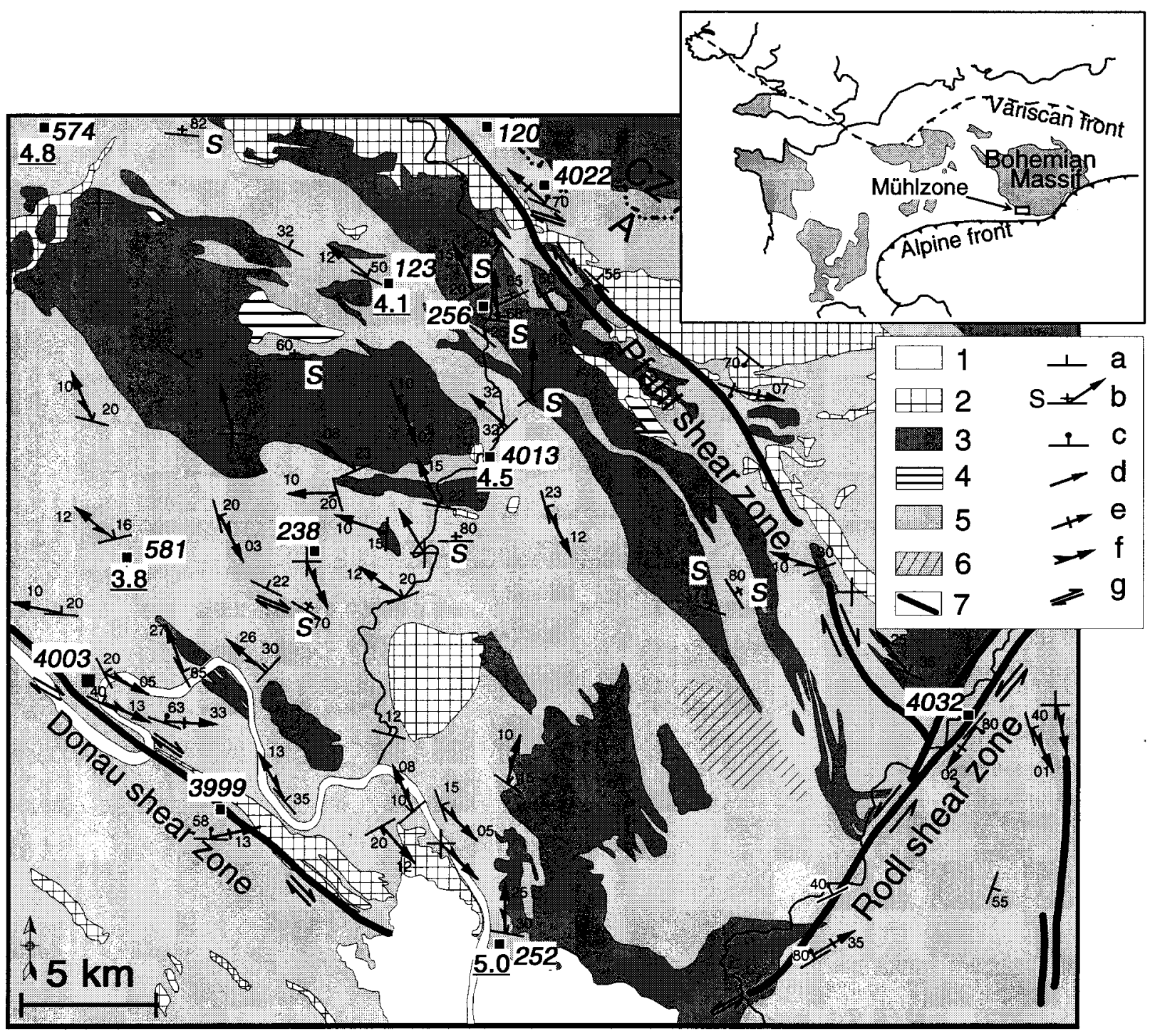

FIGURE 1. Geological map of the Mühlzone of Upper Austria (modified after Frasl et al. 1965). (1) Neogene sediments, (2) fine-grained granitoids, (3) Weinsberg granite, (4) Diorite, (5) Pearl gneisses and Schlieren granite (Pearl gneisses dominate only near the Donau shear zone), (6) Zone of Herzogsdorf, (7) D3 shear zones. (a) S2, (b) submagmatic foliation and lineation, (c) S3, (d) L2, (e) L3, (f) tectonic hanging wall transport, (g) strike-slip movements in D3 shear zones. 4013: sample localities mentioned in text. 4.5: average pressure (kbar) from Alin-hornblende barometry. Inset: The extra-Alpine Variscides in Central Europe (after Franke 1989).

In the Mühlzone, intrusion of the Weinsberg granite led to in-situ formation of the Schlieren granite (Finger and Clemens 1995). Both granites are coarse-grained and have abundant potassium feldspar megacrysts. As they are similar in texture, the size and shape of megacrysts are the only criteria by which they may be distinguished in the field. Megacrysts in the Schlieren granite are less abundant, shorter, and have greater aspect ratios than those in the Weinsberg granite (Figs. 2a and $2 \mathrm{~b})$. The modal percentage of megacrysts is $15-25$ vol\% in the Schlieren granite and 50-70 vol\% in the Weinsberg granite. Magmatic amphibole is locally present in the Schlieren granite and coexists with quartz, plagioclase, potassium feldspar, titanite, and biotite; amphibole is absent in the Weinsberg gran- ite. Detailed petrographic and genetic descriptions of most rock types in the Mühlzone can be found in Finger (1986) and Finger and Clemens (1995). The crystallization age of the Weinsberg granite has been dated at 330-320 Ma (monazite: $\mathrm{U}-\mathrm{Pb}, \mathrm{Pb}-\mathrm{Pb}$; Friedl et al. 1996). Diffuse and irregular contacts, transitional rock types, and intrusion of one granite into the other (Finger and Clemens 1995, and references therein) indicate that the Weinsberg and Schlieren granites coexisted as magmas; thus, they are of the same age.

Away from the thermal and fluid influence of the intruding Weinsberg granite, the country rocks of the Mühlzone, mainly biotite-plagioclase gneisses (so-called Pearl gneisses of Finger 1986), lack evidence of melt-forming reactions. However, closer 
to the Weinsberg granite, the Pearl gneisses become diatexite and Schlieren granite. The typical high- $T /$ low- $P$ mineral assemblage in the Pearl gneiss (Qtz-Pl-Bt \pm Sil \pm Crd \pm Kfs; mineral abbreviations after Kretz 1983) formed during the late-Variscan high-T/low- $P$ metamorphism (Finger and Clemens 1995).

Conjugate dextral (Donau- and Pfahl-shear zone) and sinistral (Rodl-shear zone) strike-slip zones (Handler et al. 1991) crosscut the Weinsberg and Schlieren granites and separate the Mühlzone from surrounding structural units (Fig. 1). Generally low- to medium-grade, but locally upper amphibolite-facies metamorphism $\left(600-650{ }^{\circ} \mathrm{C}\right)$ during shearing along the Pfahl and Rodl shear zones has been documented by Masch and Cetin (1991) and Brandmayr et al. (1995). Activity of the Donau and Rodl shear zones has been dated with ${ }^{40} \mathrm{Ar} /{ }^{39} \mathrm{Ar}$ geochronology of white mica (Brandmayr et al. 1995), and plateau ages of $287 \pm 0.6$ and $288 \mathrm{Ma}$ are interpreted as ages of cooling below $\sim 375^{\circ} \mathrm{C}$.

\section{PRE-PLUTONIC STRUCTURES}

Pre-plutonic structures (D1) are preserved in para- and orthogneisses, calc-silicate rocks, and migmatites of the Zone of Herzogsdorf (Fig. 1). These rock types have been identified as protholiths of the Pearl gneisses and Schlieren granite (Fuchs and Thiele 1965; Finger and Clemens 1995). Outside the Zone of Herzogsdorf, D1 structures are overprinted by the lateVariscan high- $T /$ low- $P$ metamorphism and are therefore not discussed in detail.

\section{MACROFABRICS OF THE MAGMATIC STAGE}

As stated above, the granites and Pearl gneisses formed during late-Variscan times under high- $T /$ low- $P$ conditions that postdated the D1 event. Structures in the Mühlzone that are related to this regional high- $T$ /low- $P$ metamorphism are referred to D2, and include magmatic fabrics in the granites and solidstate structures in the Pearl gneisses.

The Schlieren granite has a well developed and penetrative magmatic foliation (S2), defined by flat faces [i.e., (010) planes] of potassium feldspar megacrysts or plagioclase phenocrysts and by (001) of biotite (Fig. 2a). In contrast to the Schlieren granite, magmatic foliation in the Weinsberg granite (Fig. 2b) generally extends for only several meters and changes successively into an unfoliated, irregular magmatic texture. This suggests that magmatic flow in the Weinsberg granite was more turbulent than laminar, and vice versa in the Schlieren granite.
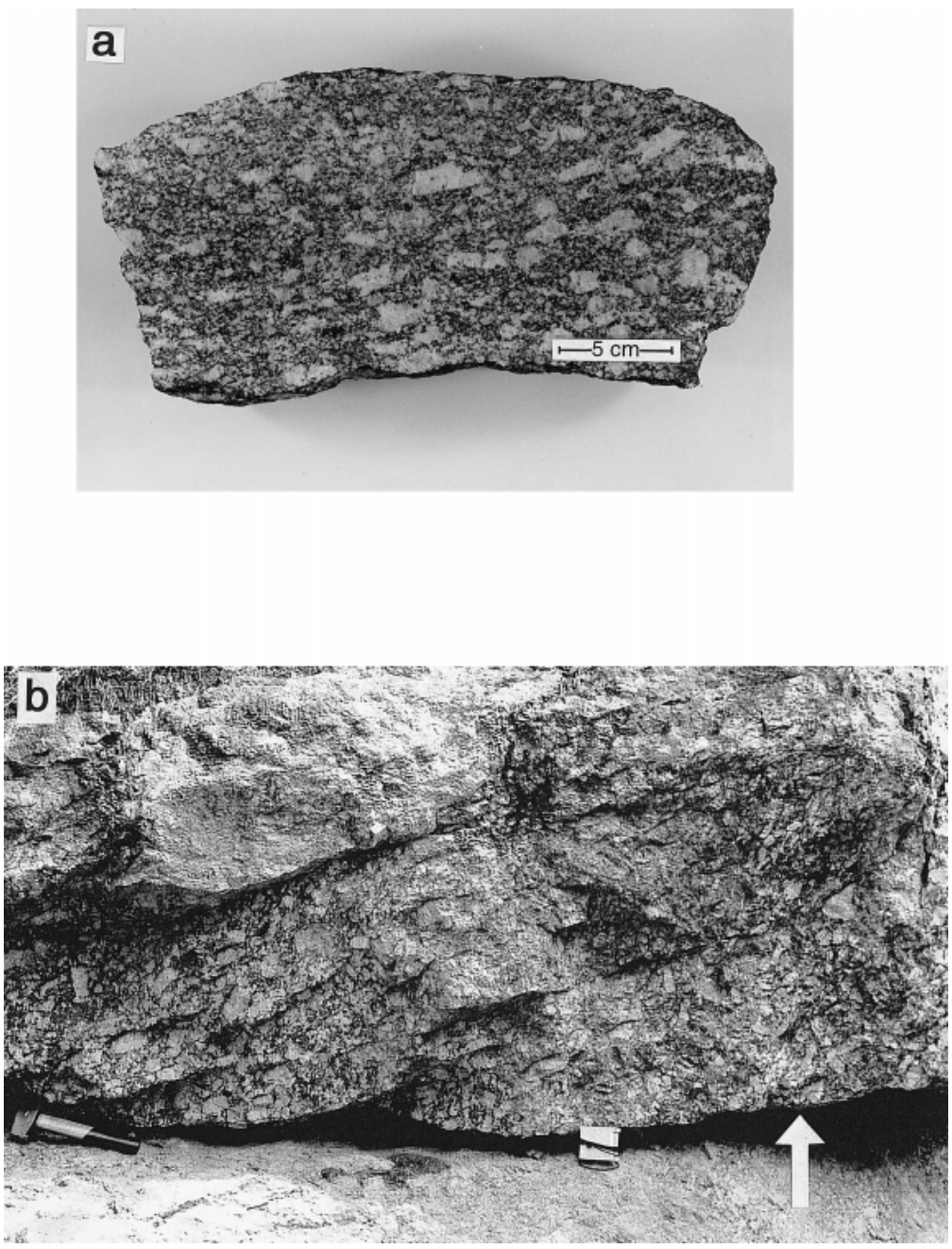

Figure 2. (a) Hand-specimen of Schlieren granite in $\mathrm{X}-\mathrm{Z}$ section, sample 238. Most potassium feldspar phenocrysts are oriented horizontally, parallel to the main magmatic foliation (S2). Bimodal distribution of potassium feldspar long axes show top-to-the-right (i.e., top SE) sense of shear (see rose diagram Fig. 4e). (b) Synmagmatic D2 fabric (left part) and type A submagmatic shear zone (above white arrow) in Weinsberg granite (Loc. 256). Bimodal distribution of potassium feldspar long axes (left part between hammer and compass) show top-to-the-right (i.e., topto-the-SE) sense of shear (see rose diagram Fig. 4a). Long axes maxima are flat-lying or dip to the left. In the type A submagmatic zone above the white arrow, most of the potassium feldspar long axes are oriented steeply. Length of hammer: $28 \mathrm{~cm}$. 
Further evidence for the magmatic origin of these structures is discussed in the microfabric section below. The magmatic foliation (S2) in both the Weinsberg and Schlieren granites dip at low angles to the NE to NW or is approximately horizontal. D2 lineations in the granites dip at low angles to the NW or SE (Figs. 1 and 3). L2 in the granites is defined by the flat faces and long axes of potassium feldspar and plagioclase phenocrysts. Potassium feldspar phenocrysts in X-Z sections show asymmetric (monoclinic), usually bimodal distribution patterns of long-axis orientations (Figs. $2 a, 2 b$, and 4 ). The main maximum of potassium feldspar long axes is parallel to the magmatic foliation. A smaller maximum forms an angle of $\sim 15-35^{\circ} \mathrm{C}$ with the magmatic foliation. Such distribution patterns have been interpreted as the result of phenocryst rotation in the magma due to noncoaxial deformation (e.g., Arzi 1978; van der Molen and Paterson 1979; Blumenfeld and Bouchez 1988; Benn and Allard 1989; Nicolas 1992). This distribution pattern has been observed in 21
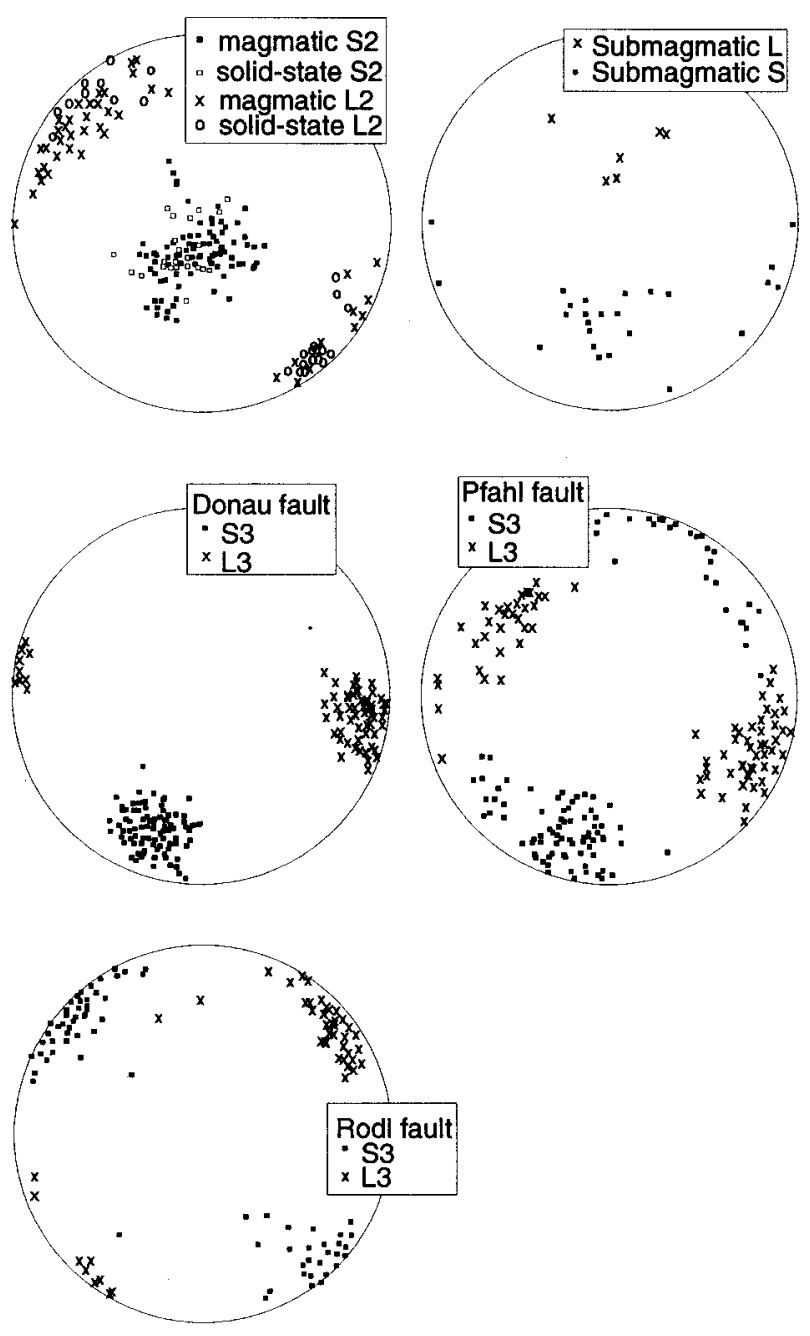

FIGURE 3. Schmidt net diagrams (lower hemisphere) with the orientation of D2, submagmatic, and D3 structures. L: lineation; S: magmatic foliation or solid-state cleavage.

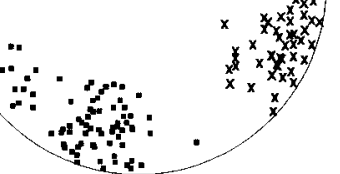

of 49 exposures of the Schlieren and Weinsberg granites. It indicates a shear sense during the synmagmatic deformation (D2) of top-to-the-ESE to top-to-the-SSE (Figs. 1, 2, and 4). The abundance of magmatic foliations and D2 shear fabrics suggests that this magmatic low-angle thrusting affected large parts of the granites, although the bimodal phenocryst patterns are not always present.

The metamorphic layering in the Pearl gneisses consists of quartz-plagioclase-rich and biotite-rich layers. Oriented biotite and the flat faces of recrystallized quartz and feldspar lenses define the main cleavage (S2). Metamorphic layering and S2 are mostly parallel. D2 stretching lineations (L2) on S2 are defined by elongate biotite, quartz, and feldspar lenses, by fibrolitic sillimanite, and locally by the long axes of cordierite porphyroblast. Generally, the D2 macrofabrics in the Pearl gneisses and the granites have similar orientations (Fig. 3). Shear-sense indicators in the Pearl gneisses, such as plagioclase $\sigma$-clasts and S-C fabrics defined by biotite, indicate hanging-wall transport to the SE during D2 (Figs. 1 and 5a). Parallelism of macrofabrics, transport directions, similar metamorphic grade, and the transitional rock types between Pearl gneiss, diatexite, and Schlieren granite (Finger 1986) all suggest that $\mathrm{D} 2$ in the Pearl gneiss and granites was more or less coeval.
NW

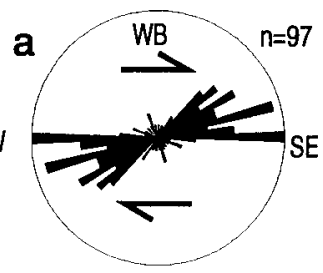

Pfahl fault

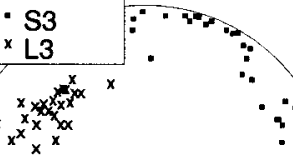

NW

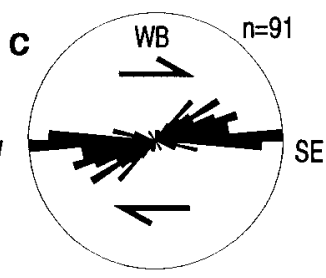

NNW

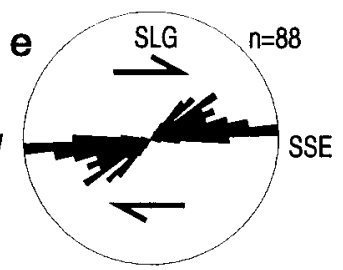

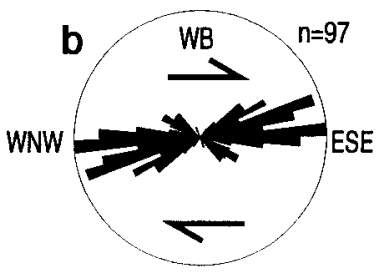
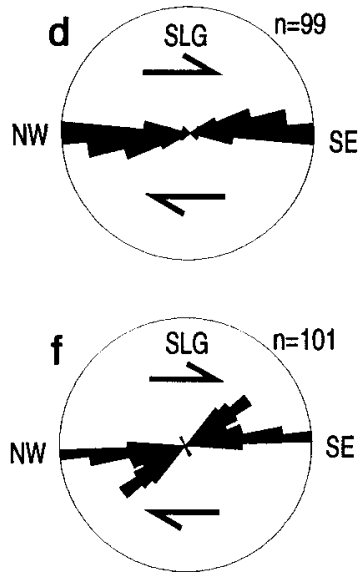

FigURE 4. Rose diagrams showing the orientation of potassium feldspar phenocryst long axes in the Weinsberg (WB) granite (a-c) and Schlieren (SLG) granite (d-f) in relation to the magmatic foliation (parallel to the main maxima). The segments represent the frequency of rotated marker long axes (phenocrysts) in the corresponding angular difference to the main magmatic foliation. In the Weinsberg granite $(\mathbf{a}-\mathbf{c})$, phenocryst long axes in the upper left and lower right quadrant may result from tiling effects due to the high modal content of phenocrysts. 


\section{MICROFABRICS IN D2 STRUCTURES}

Most of the plagioclase and microcline crystals in the Schlieren and Weinsberg granites are undeformed. Oscillatory zonation in plagioclase, and euhedral crystal faces of plagioclase and microcline phenocrysts against quartz (Fig. 5b), highlight their magmatic origin (Vernon 1986; Vernon and Collins 1988; Paterson et al. 1989). Locally, plagioclase shows deformation twins, but recrystallization or formation of subgrains in magmatic feldspar are absent in D2 structures. The rims of potassium feldspar crystals were largely replaced by myrmekite, from which a polygonal plagioclase fabric has been formed with equilibrated grain boundaries that meet at $120^{\circ}$ triple junctions (Fig. 5c). Swarms of rounded quartz inclusions commonly have a similar lattice orientation in individual plagioclase crystals. Part of the myrmekite survived plagioclase formation and is strain-free. Therefore, the driving force of myrmekite replacement appears to be grain boundary area reduction during postmagmatic textural maturation. Biotite is generally undeformed, but bending has led to undulose extinction or subgrain formation in rare examples.

Interstices between feldspars and biotite flakes in the Weinsberg and Schlieren granites are filled with a small number (usually 1-4) of large (500-2500 $\mu \mathrm{m})$ quartz grains with straight or coarsely serrated grain boundaries. Depending on the shapes of the interstices, quartz grain shapes are either isometric or irregular. Elongate or lens-shaped quartz grains do not occur in D2 structures. Quartz grain boundaries commonly include high angles with the basal and prism plane and possibly are oriented parallel to the rhombohedral or trapezohedron plane. Chessboard patterns (a combination of prism and basal parallel subgrain boundaries; Kruhl 1996) are present in almost all samples of the granites (Fig. 5b) and indicate prism C-slip, which is restricted to the stability field of high-quartz (Kruhl 1996, 1998). Several explanations are possible for the presence of subgrains in quartz. Firstly, strain related to regional tectonics ("external" strain) could deform the quartz during and after the solidification of the granites. Recovery at high temperatures (stability field of high-quartz) may facilitate the formation of chessboard patterns and explains minor grain-boundary migration that forms coarsely serrated grain boundaries. "Internal" strain resulting from volume changes within the pluton during solidification could produce the same textures as "external" strain, but would not be related to a regional deformation. A third explanation for chessboard patterns in magmatic quartz could be the recovery of dislocations that were introduced into the crystal lattice during magmatic growth. The amount of growth dislocations in a crystal correlates positively with temperature and growth rate (Elwell and Scheel 1975), providing a high dislocation density in magmatic crystals. It was not possible to determine the relative importance of these processes for the development of dislocations in D2 quartz. Taking into account that grain-boundary migration is only weakly evolved, and no relationship between grain-boundary orientation and any foliation is recognizable, the influence of "external" strain was probably small. Thus, quartz in D2 fabrics of the granites is interpreted as magmatic, and possibly experienced weak deformation during or shortly after crystallization.

D2 microfabrics in the Pearl gneisses formed by solid-state deformation. Pearl gneisses have rounded plagioclase crystals
2-4 $\mathrm{mm}$ in diameter, which locally show magmatic zonation (euhedral shape of sharply defined growth zones) suggesting a former magmatic stage. The critical metamorphic mineral assemblage is Qtz-Sil-B $\pm \mathrm{Kfs} \pm \mathrm{Crd}\left(X_{\mathrm{Fe}} \approx 0.35\right)$, indicating high$T /$ low- $P$ conditions. Quartz lenses show chessboard patterns preferentially in large grains elongated parallel to $S 2$, indicating D2 deformation in the stability field of high-quartz (Kruhl 1996). The quartz grain size varies between $50 \mu \mathrm{m}$ and $800 \mu \mathrm{m}$ depending on the extent of grain-size reduction by dynamic recrystallization. Grain boundaries are irregular and finely serrated.

Summarizing the observations in the above sections, macroand microstructures in the granites indicate magmatic flow during D2, whereas indications of plastic deformation are lacking or are present only as chessboard patterns in quartz. Magmatic low-angle thrust zones point to top-to-the ESE to SSE transport, similar to coeval solid-state structures in the Pearl gneisses.

\section{SUBMAGMATIC STRUCTURES}

The following section describes the progressive evolution of structures in the range of the granite solidus, which led to a change in shear-plane orientation and to increasing importance of plastic deformation of feldspar. The term "submagmatic" is used here to mean a stage of crystallization with less than the critical amount of residual melt that is necessary for magmatic flow (Paterson et al. 1989; Bouchez et al. 1992). The rheology in the submagmatic stage is largely controlled by an interconnected framework of solid phases, rather than by residual melt in interstices.

Submagmatic structures from the intrusive and well-homogenized Weinsberg granite have been selected for detailed investigations to avoid pre-magmatic restitic microstructures, which might be present in the Schlieren granite. Two types of structures that suggest submagmatic deformation occur in both the Weinsberg and the Schlieren granites at eight locations.

(1) The first includes $1-3 \mathrm{~m}$ wide, approximately $\mathrm{E}-\mathrm{W}$ striking zones with a steep to vertical foliation (type A submagmatic shear zones). This foliation is defined by flat faces of potassium feldspar phenocrysts and oriented biotite, but is diffuse and irregular (Fig. 2b). Macroscopically, phenocrysts and matrix minerals look magmatic. In the microfabric, large quartz crystals ( $\leq 4 \mathrm{~mm}$ diameter) are isometric or irregular in shape with straight or locally coarsely serrated grain boundaries, indicating minor grain-boundary migration. The modal quartz content in type A submagmatic shear zones is the same as in D2 structures. Plagioclase phenocrysts show slight magmatic zonation with cores being $\mathrm{An}_{32}$ and rims $\mathrm{An}_{29}$. Some of these grains are considerably deformed and show subgrains and coarse recrystallization $(250-2000 \mu \mathrm{m}$ in diameter) by subgrain rotation (Fig. 5d). In subgrains and recrystallized grains, anorthite contents are slightly lower $\left(\mathrm{An}_{27}-\mathrm{An}_{30}\right)$ but overlap with those in undeformed parts of the phenocrysts $\left(\mathrm{An}_{29}-\mathrm{An}_{32}\right)$. This suggests that the $P-T-X$ environment during plastic deformation was approximately the same as during magmatic growth of the phenocrysts. The presence of only slightly deformed magmatic quartz next to recrystallized plagioclase phenocrysts suggests the presence of residual melt during plagioclase deformation. 

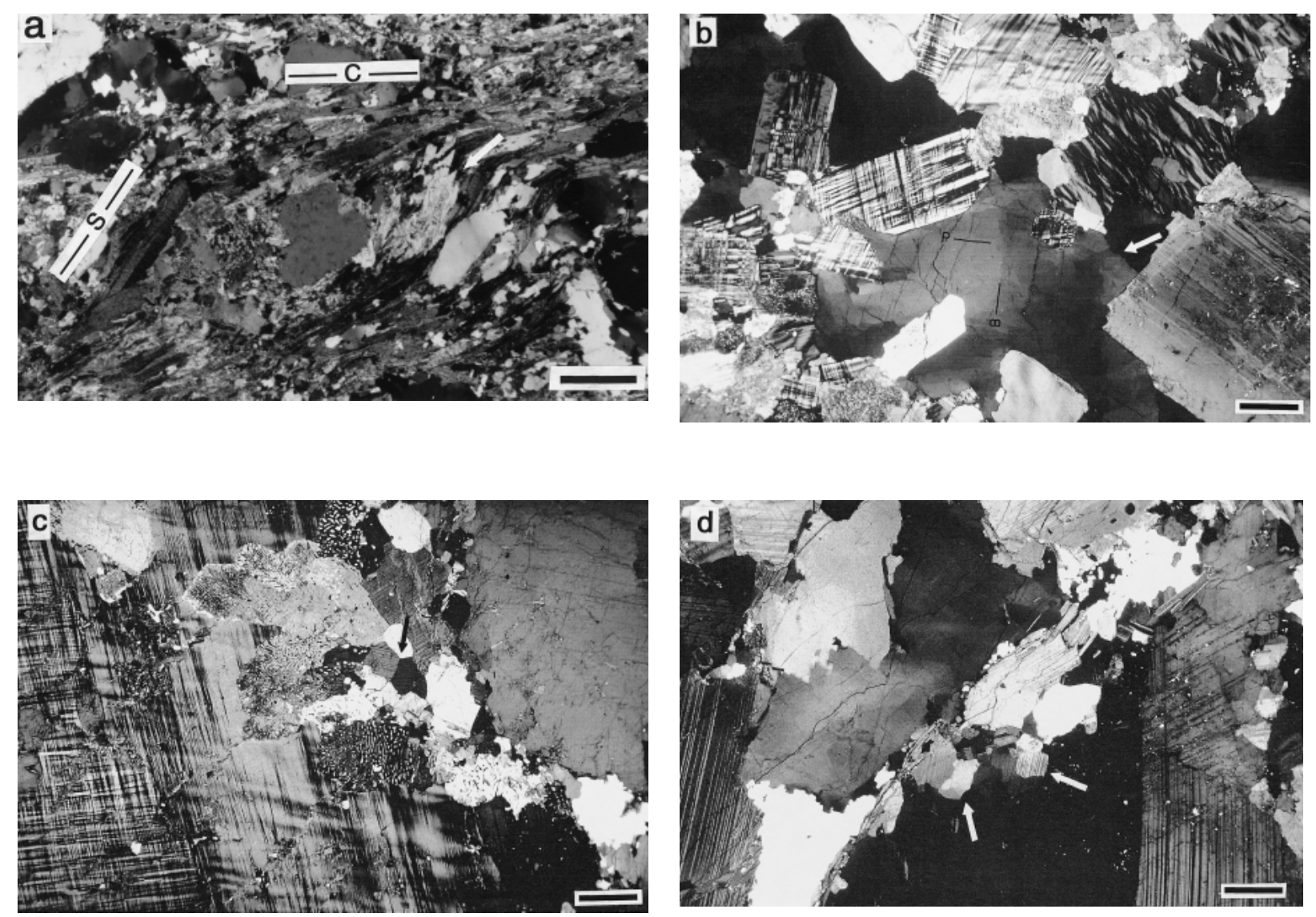

FIGURE 5. Thin section photographs, crossed polarizers, scale $600 \mu \mathrm{m}$ unless stated otherwise. (a) Solid-state D2 S-C fabric in Pearl gneiss indicate a hanging wall transport to the right (i.e., SE). Post-kinematic white mica overgrew D2 fabric (arrow). Sample 4003, X-Z section, scale: $800 \mu \mathrm{m}$. (b) Plagioclase and potassium feldspar phenocrysts in magmatic quartz matrix. Quartz shows chessboard subgrain patterns. B: basis plane, P: prism plane. Note straight or coarsely serrated grain boundaries (arrow) and weak magmatic zonation in the plagioclase (right). Weinsberg granite (WB), sample $256 \mathrm{~B}$. (c) Myrmekite, partly replaced by plagioclase, shows equilibrated grain boundaries with $120^{\circ}$ triple points (arrow). Remaining myrmekite is undeformed, WB, sample 564 A, Loc. 256, scale $400 \mu \mathrm{m}$. (d) Plagioclase phenocryst (An $\left.{ }_{29-32}\right)$ from submagmatic shear zone type A. Left part of Carlsbad twin in extinction position, showing recrystallization and formation of subgrains ( $\mathrm{An}_{27-30}$,

(2) The second and more prominent type of submagmatic structure consists of zones with a tight foliation defined by parallel-oriented potassium feldspar phenocrysts and (001) of biotite plates (type B submagmatic shear zones, Figs. 6a and 6b). These zones are $0.5-4 \mathrm{~m}$ thick and dip $50-65^{\circ}$ to the $\mathrm{N}$ or are parallel to the Rodl and Pfahl shear zones (Figs. 1 and 3). In type $\mathrm{B}$ zones, steeply plunging feldspar stretching lineations and coarse S-C fabrics suggest top-to-the-south transport. In the field, these reverse shear zones appear to be solid-state phenomena, because of the tight foliation and recrystallization of feldspar, and even the latter is visible macroscopically (Fig. 6b). Microfabrics of these zones show plastic deformation of most feldspar phenocrysts indicated by lattice bending, subgrains, and recrystallization. In part, plagioclase phenocrysts are completely recrystallized and show equigranular patterns with equilibrated grain boundaries (Fig. 5e); recrystallized grains range up to 800 $\mu \mathrm{m}$ in size. The composition of plagioclase subgrains and recrystallized grains is similar $\left(\mathrm{An}_{24-27}\right)$, but different from undeformed phenocrysts $\left(\mathrm{An}_{30-33}\right)$. The anorthite content of recrystallized grains and subgrains in type B zones is also lower than in type A zones. The analyzed samples from zones of type A and B come from the same exposure (Loc. 256, Fig. 1). However, there are clear indications for the presence of residual melt in type B zones during plastic deformation of plagioclase. Intragranular fractures in plagioclase phenocrysts are sealed with quartz and partly with plagioclase, and the quartz commonly continues from inside of to outside the phenocryst, usually as one or few large grains (Fig. 5f). Similar fabrics have been described by Bouchez et al. (1992) as "submagmatic microfractures," indicating the presence of melt during fracturing. Reaction rims of up to $300 \mu \mathrm{m}$ occur along the fractures (Fig. 5f) and show a lower anorthite content $\left(\mathrm{An}_{24-27}\right.$, locally $\mathrm{An}_{20-}$ $\left.{ }_{21}\right)$ than the phenocrysts away from the rims $\left(\mathrm{An}_{30-33}\right)$. These rims do not occur at undeformed boundaries of plagioclase phenocrysts, which suggests that fracturing facilitated the chemical reaction of phenocrysts with residual melt during the submagmatic 

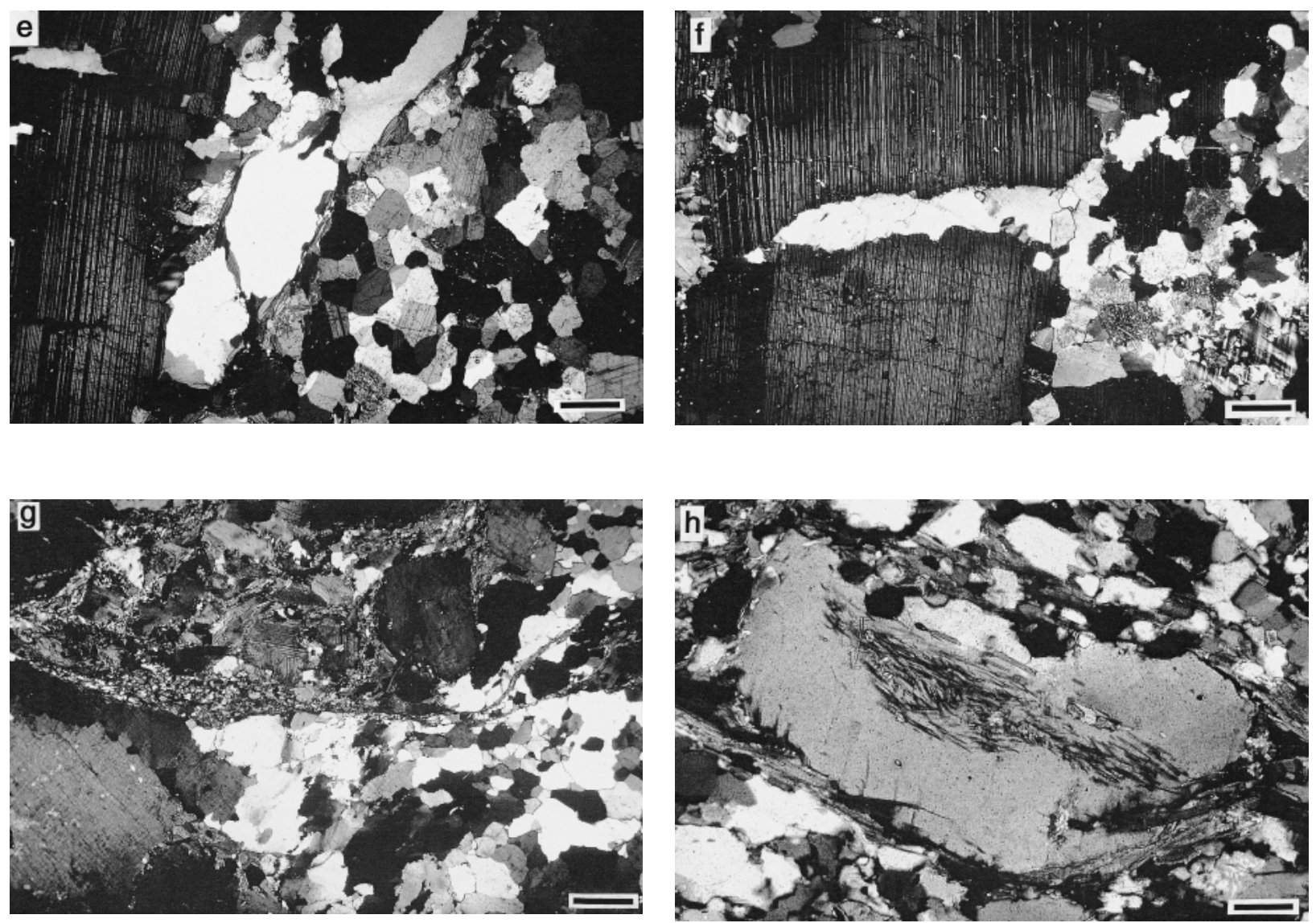

arrows). Quartz shows coarsely serrated grain boundaries indicating beginning of grain boundary migration. WB, sample 564A, Loc. 256. (e) Magmatic quartz between recrystallized plagioclase (right, $\mathrm{An}_{24-27}$ ) and plagioclase phenocryst (left, $\mathrm{An}_{29-33}$ ). Thin section from submagmatic reverse shear zone (type B) in Figure 6a. WB, sample 256, Loc. 256. (f) Reaction rim $\left(\mathrm{An}_{24-27}\right.$, locally $\left.\mathrm{An}_{20-21}\right)$ along submagmatic microfracture in plagioclase phenocryst $\left(\mathrm{An}_{30-33}\right)$. The fracture is filled with magmatic quartz. Same thin section as in Figure 5e. (g) Fine-grained recrystallization of plagioclase (upper part) and quartz (center). In the right part, quartz grain-coarsening and equilibration of grain boundaries. Protomylonite from the Pfahl shear zone, Loc. 120. (h) Sillimanite and biotite inclusions in cordierite. High-T mylonite from the Pfahl shear zone. Loc. 4022, scale $500 \mu \mathrm{m}$.

stage. The similarity in composition of the reaction rims at submagmatic microfractures and recrystallized grains indicates that fracturing and recrystallization were more or less coeval. Microfracture orientations are perpendicular to polysynthetic twin lamellae and long axes of phenocrysts, and because of the welldefined alignment of the feldspars, these orientations are also approximately orthogonal to the foliation. Therefore, it remains unclear whether microfracture orientation is controlled by the orientation of the stress field, the plagioclase lattice, or both. Large grains of weakly deformed magmatic quartz surround the recrystallized plagioclase phenocrysts (Fig. 5e). The modal percentage of quartz in type B zones is lower than in type A zones and D2 structures.

The submagmatic stage in the granites of the Mühlzone is characterized by plastic deformation of feldspars in an interconnected framework of solid phases with residual melt in the interstices. Submagmatic type A zones were active at $\left(P_{-}\right) T-X$ conditions similar to those of $\mathrm{D} 2$. In type B submagmatic re- verse shear zones, decrease of anorthite content in deformed and recrystallized plagioclase suggests lower $T$ or decrease of Ca in the residual melt during deformation. Submagmatic zones are generally steeper than D2 shear planes and are oriented either perpendicular to the shortening direction or parallel to D3 shear zones.

\section{MACRO- AND MICROSTRUCTURES IN CONJUGATED STRIKE-SLIP SHEAR ZONES}

Conjugate strike-slip zones cut D2 fabrics of the Mühlzone (Fig. 1). The largest of these are the sinistral Rodl, and the dextral Donau and Pfahl shear zones (Handler et al. 1991; Brandmayr et al. 1995), but many smaller ones occur within the Mühlzone. The most prominent structures in these shear zones are a mylonitic foliation (S3) and gently plunging stretching lineation (L3), the orientations of which are shown in Figure 3. Depending on strain intensity, and the abundance and size of porphyroclasts (usually potassium feldspar and plagio- 
clase), the foliation is either a continuous cleavage or a spaced schistosity (Passchier and Trouw 1996). S3 is defined by quartz ribbons and oriented micas (Ms, Bt), and L3 in all shear zones is a quartz, mica, or feldspar stretching lineation. Stretching is evidenced by recrystallized quartz and feldspar parallel to L3 in porphyroclast pressure shadows. The sense of shear (dextral in the Donau and Pfahl shear zones, sinistral in the Rodl shear zone) is evidenced by S-C fabrics, feldspar $\sigma$ - and $\delta$-clasts, and local flexures. Mylonites located along these shear zones contain the mineral assemblage Qtz-Pl-Kfs-Bt-Ms.

Quartz in D3 fabrics shows recrystallization by grain-boundary migration along fine serrated grain boundaries (serration $10-50 \mu \mathrm{m}$, Fig. $5 \mathrm{~g}$ ), and locally by subgrain rotation. Grainboundary migration has changed the shape of magmatic quartz to elongated smaller grains or grain aggregates oriented parallel to S3. This grain-shape transition is apparent in the less
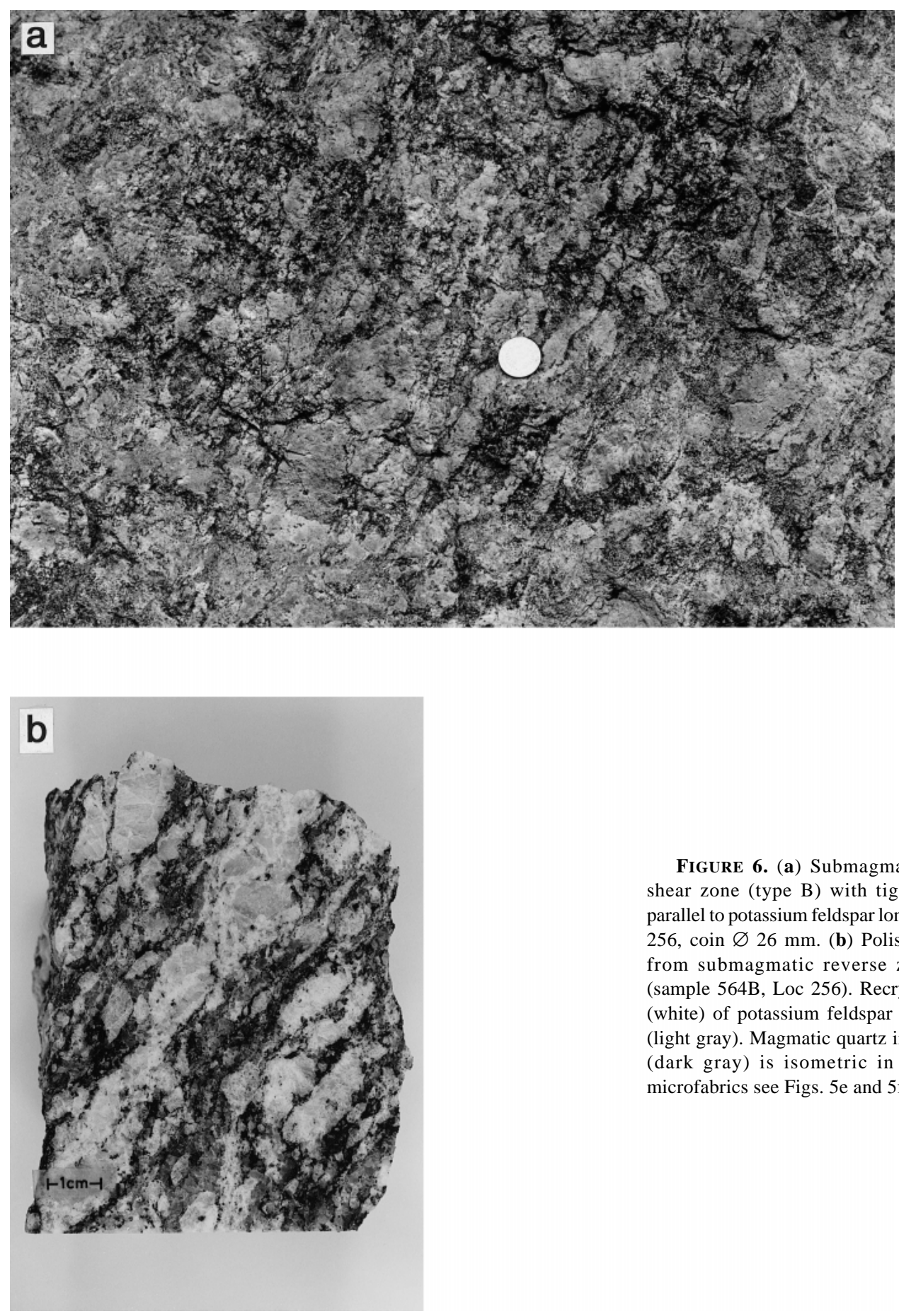

Figure 6. (a) Submagmatic reverse shear zone (type B) with tight foliation parallel to potassium feldspar long axes; Loc. 256, coin $\varnothing 26 \mathrm{~mm}$. (b) Polished sample from submagmatic reverse zone in (a) (sample 564B, Loc 256). Recrystallization (white) of potassium feldspar phenocrysts (light gray). Magmatic quartz in the matrix (dark gray) is isometric in shape (for microfabrics see Figs. 5e and 5f). 
deformed marginal parts of the D3 zones, whereas in the central part of the shear zones, magmatic textures have survived only as oscillatory zonation in plagioclase porphyroclasts. Here, the matrix is ultramylonitic with strong grain-size reduction that affected mainly quartz and mica. Feldspars show a wide range of deformation fabrics, including cracks, bending, kink bands, and deformation twins that suggest deformation under $P-T$ conditions below the minimum temperature for feldspar recrystallization $\left(450-500{ }^{\circ} \mathrm{C}\right.$ : Voll 1976; Altenberger et al. 1987; Tullis and Yund 1991). However, fabrics that indicate amphibolite-facies deformation temperatures are common. In many cases fractured feldspar (both plagioclase and potassium feldspar) shows recrystallization along intragranular fracture planes or grain boundaries (Fig. $5 \mathrm{~g}$ ). The recrystallized grains are small $(\sim 10-20 \mu \mathrm{m}$ diameter) and present mainly in samples that show quartz foam structure. These observations suggest fracturing of feldspar due to deformation (which also affected quartz) at high strain-rate followed by (static?) recrystallization slightly above the recrystallization temperature of feldspar. Deformation at greenschist-facies $P-T$ conditions in the Pfahl, Donau, and Rodl shear zones is described in detail by Handler et al. (1991) and Brandmayr et al. (1995).

Evidence for shearing at high-grade $P$ - $T$ conditions along the Pfahl shear zone has been observed in only one exposure, but has previously been reported from other parts of the Pfahl (Masch and Cetin 1991). In the other strike-slip zones, this event may have been overprinted by later amphibolite-facies and greenschist-facies deformation. High temperature is indicated by the synkinematic growth of cordierite and sillimanite in an ultramylonite (Loc. 4022, Fig. 1). Both minerals are aligned parallel to the mylonitic structures (S3, L3) and are only locally weakly deformed. Cordierite forms oval-shaped, clearblue crystals with long axes generally 3-5 mm (Fig. 5h) and rarely up to $2 \mathrm{~cm}$; some crystals contain sillimanite inclusions. Cordierite in the Pfahl mylonites $\left(X_{\mathrm{Mg}}=0.56-0.60\right)$ and the Pearl gneisses $\left(X_{\mathrm{Mg}}=0.63-66\right)$ are different in size, abundance, and chemical composition. Furthermore, the protholiths of the Crd-Sil-mylonites are (Crd-free) Schlieren granite and Weinsberg granite (Sturm 1995; F. Finger, personal communication 1997); thus, pre-mylonitic cordierite growth can be excluded. Matrix quartz is fine-grained $(50-100 \mu \mathrm{m})$ owing to grain size reduction during mylonitization. Quartz in monomineralic layers has a large grain size (up to $1.5 \mathrm{~mm}$ ) with coarsely serrated $(50 \mu \mathrm{m})$ grain boundaries. These quartz layers originally may have been large single crystals (platy quartz) with lengths of $\sim 2 \mathrm{~cm}$ and thicknesses of $\sim 1.5 \mathrm{~mm}$ before recrystallization.

Chessboard subgrain patterns indicate D3 deformation in the stability field of high-quartz (Kruhl 1996). Potassium feldspar and plagioclase porphyroclasts show coarsely recrystallized rims (recrystallized grains up to $200 \mu \mathrm{m}$ diameter). In the high- $T$ mylonites, there is no evidence for synkinematic prensence of melt.

Summarizing the above observations, an initial postmagmatic, high- $T$ stage of deformation occured in D3 shear zones within the stability field of cordierite, sillimanite, and high-quartz, and it was followed by lower amphibolite-facies deformation. The latter dominates in the structures of $\mathrm{D} 3$ shear zones, whereas deformation at higher or lower temperature is present but less abundant. The orientations of macrostructures were uniform from high- to low-grade $P$ - $T$ conditions.

\section{THERMOBAROMETRY}

Thermobarometric estimations support the similarity of $P$ $T$ conditions during soldification of the granites and the high- $T$ mylonitization in the Pfahl shear zone. Electron microprobe analyses were obtained with a wavelength-dispersive CAMECA Camebax SX 50 instrument (using the PAP correction procedure) at the Mineralogisch-Petrologisches Institut of the Universität Bonn, and a CAMECA Camebax Microbeam instrument (using combined PAP/XMAS correction procedure) at the Technische Universität Berlin. An accelerating potential of $20 \mathrm{kV}$ and a beam current of 15-18 nA were used. Beam diameters were $4 \mu \mathrm{m}$ for amphibole and mica analyses, and 10 $\mu \mathrm{m}$ for feldspar analyses.

\section{$P-T$ conditions of the Schlieren granite solidification}

The late-magmatic stage $P-T$ conditions of the Schlieren granite were determined from five amphibole-bearing samples using amphibole-plagioclase thermometry (Holland and Blundy 1994) and Al-in-hornblende barometry (Schmidt 1992), which was corrected for temperature after Anderson and Smith (1995). All samples (apart from 4013) contain the required assemblage for Al-in-hornblende barometry (Hbl-Pl-Qtz-Kfs-Ttn-Fe,Tioxide- $\mathrm{V}$ ). Most of the amphiboles are magnesio or edenitic hornblendes with 6.50-6.85 Si per formula unit (pfu) and $X_{\mathrm{Mg}}$ $=0.50-0.68$ (Fig. 7). The cores generally have slightly higher $\mathrm{Si}$ than the rims. The total $\mathrm{Al}$ content varies from sample to sample and within individual samples (Tables 1 and 2). In samples 123A and 4013, total Al content increases towards the cores. The difference of $\sim 0.1 \mathrm{Al}$ pfu yields a $0.5 \mathrm{kbar}$ higher pressure for core compositions. However, these are not interpreted as geologically significant. Plagioclase generally shows weak zonation, with $\mathrm{Na}$ increasing from core to rim (Table 1). However, in sample 123A, plagioclase has a more or less homogeneous composition of $\sim \mathrm{An}_{30}$. Sample 4013 is an $\sim 1 \times 3$ $\mathrm{cm}$ mafic enclave in the Schlieren granite. Microtextures show evidence for high- $T$ solid-state equilibration but there is no evidence for the presence of former melt within the enclave. This mineral assemblage does not comply with the limitations for the Al-in-hornblende barometer (potassium feldspar is absent). Nevertheless, the calculated $P-T$ conditions are in the range of the Schlieren granite (Table 1). Amphibole-plagioclase parageneses in all investigated samples equilibrated at a temperature of $700 \pm 30{ }^{\circ} \mathrm{C}$ (Fig. 8). Because subsolidus reactions of the magmatic phases cannot be excluded, it is probable that the Schlieren granite solidus may be in the upper part of this temperature interval. Average pressure estimates from Al-in-hornblende barometry for the solidification of the Schlieren granite give an interval of 3.8-5.0 kbar. Because of their coexistence as magmas, this crustal level is probably also the depth of intrusion of the Weinsberg granite.

\section{$P$ - $T$ conditions in D3 shear zones}

Cordierite in high- $T$ mylonites of the Pfahl shear zone coexists with sillimanite, potassium feldspar, plagioclase, biotite, 
and quartz. Sillimanite and biotite inclusions (Fig. 5h) indicate that cordierite formed via the reaction $\mathrm{Bt}+\mathrm{Sil}+\mathrm{Qtz}=\mathrm{Crd}+$ $\mathrm{Kfs}+\mathrm{V}$, which has been calibrated as a geobarometer (Holdaway and Lee 1977). Cordierite $X_{\mathrm{Fe}}$ is between 0.40-0.44 (sample 4022, Fig. 1). The minimum temperature in these mylonites is given by the presence chessboard patterns in recrystallized platy quartz, which indicate the stability field of high-quartz (Kruhl 1996). Owing to lack of evidence for melt during mylonitization, the maximum temperature was probably the solidification temperature of the Schlieren granite $\left(\sim 700{ }^{\circ} \mathrm{C}\right)$. This temperature interval restricts the $P-T$ conditions of the high- $T$ stage of the Pfahl shear zone to 3.3-4.0 kbar at $650-700{ }^{\circ} \mathrm{C}$ (Fig. 8).

The equilibration conditions of biotite-muscovite parageneses in each of the three major shear zones indicate amphibolite-facies $P-T$ conditions during D3 shearing. Phengite barometry (Massonne and Schreyer 1987) and muscovite-biotite thermometry (Hoisch 1989) yield pressures of 3.7-4.0 kbar at temperatures of $530-620^{\circ} \mathrm{C}$ for micas in the Rodl shear zone. Micas from the Donau and Pfahl shear zone yield lower pressures and temperatures at the transition of amphibolite- to greenschist-facies: $1.8-3.1 \mathrm{kbar}$ at $472-510^{\circ} \mathrm{C}$ (Fig. 8). In most cases the chemical composition of biotites is slightly out of the

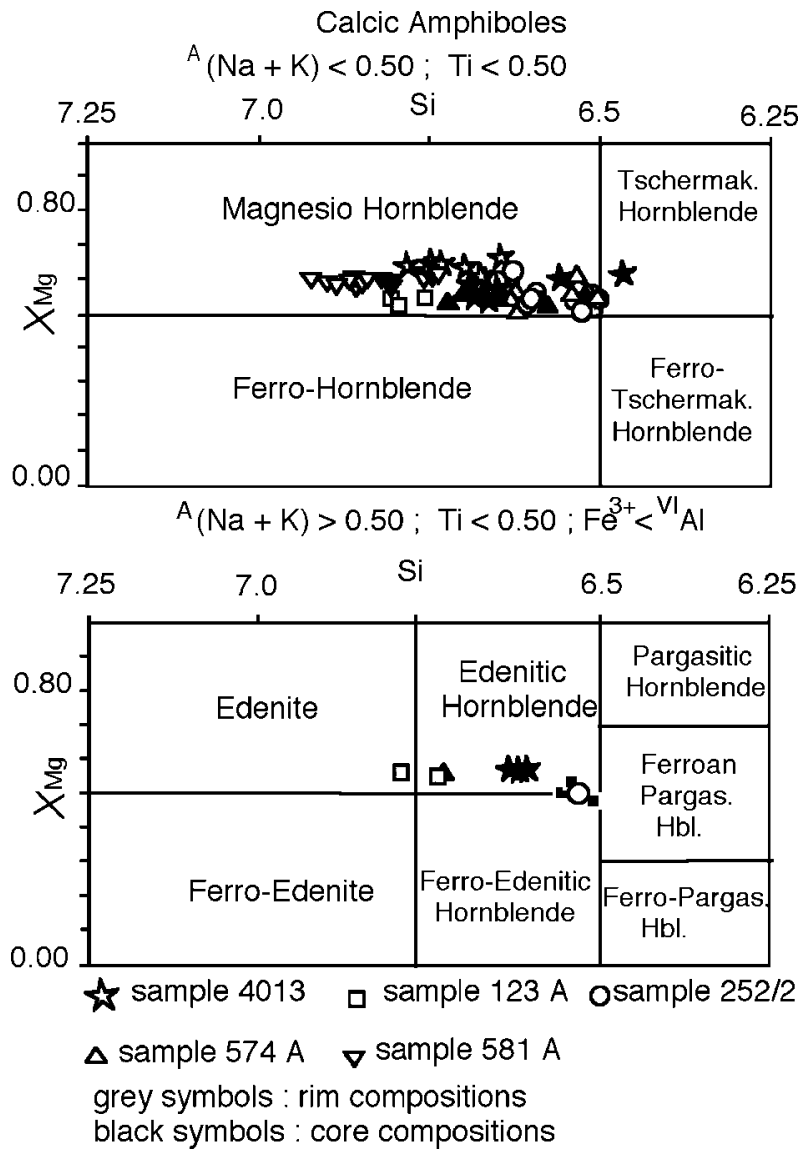

FIGURE 7. Representative compositions (45\% of data) of magmatic amphibole, field after Leake (1978). range necessary for the empirical geothermometer of Hoisch (1989). Some of the white micas show non-phengite substitutions, such as ferri-muscovite and Ti-muscovite, and only 28 of 73 analyzed micas were suitable for thermobarometry. As the calculated $P-T$ conditions are consistent with the temperature estimation from textural evidence, they are interpreted as geologically significant.

\section{DISCUSSION}

During the magmatic stage (D2), non-coaxial deformation led to the formation of low-angle thrust zones that indicate ESE to SSE hanging-wall transport along NE- to NW-dipping shear planes. This suggests approximately NS-directed contraction during D2. The magmatic D2 deformation in the granites is more or less coeval with solid-state shearing in the Pearl gneisses, which reflects the same kinematics. The D2 event was probably already under way before the Weinsberg granite intruded and the Schlieren granite was formed, but it continued until the submagmatic stage of the granites. Most of the amphibole-plagioclase $P$ - $T$ calculations suggest equilibration pressure between $\sim 3.8-5.0 \mathrm{kbar}$ (Fig. 8), which corresponds roughly to a depth of $\sim 11-15 \mathrm{~km}$. Because the sample localities are separated by distances of 6 to $28 \mathrm{~km}$ (Fig. 1), the differ-

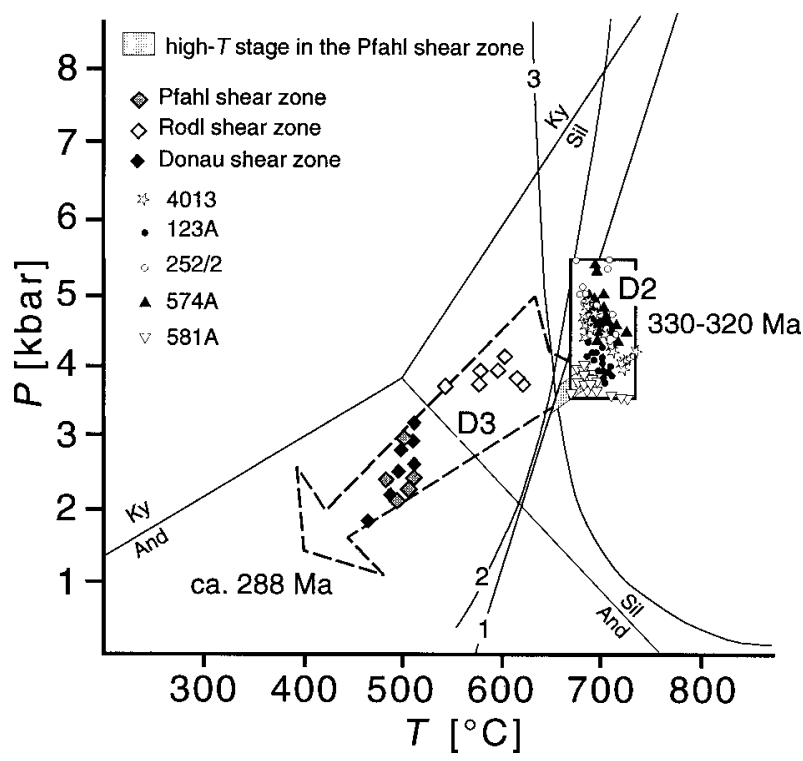

Figure 8. $P-T-d-t$ development of the Schlieren granite and D3 shear zones. Stars, circles, triangles: representative results $(70 \%$ of data) for coexisting Amp-Pl compositions in Schlieren granite. High$T$ stage in the Pfahl: Crd-Bt barometry in mylonites sample 4022E. Squares: coexisting Ms-Bt parageneses from the D3 shear zones. Pfahl shear zone, sample 4022A, Donau shear zone sample 3999, Rodl shear zone sample 4032. Sample localities are shown in Figure 1. (1) lowhigh-quartz transition from van Groos and Heege (1973). (2) Muscovite-out from Spear and Cheney (1989) (Ms + Qtz = Kfs + Als $+\mathrm{H}_{2} \mathrm{O}$ ). (3) "wet" granite solidus from Holland (1979). $\mathrm{Al}_{2} \mathrm{SiO}_{5}$ phase diagram from Holdaway (1971). 
TABLE 1. Results of Al-in-hornblende thermobarometry for the Schlieren granite

\begin{tabular}{llcccccccc}
\hline \hline Sample & $\begin{array}{c}\mathrm{X}_{\text {An }}^{\text {ore }} \\
(\mathrm{PI})\end{array}$ & $\begin{array}{c}\mathrm{X}_{\mathrm{An}}^{\text {im }} \\
(\mathrm{Pl})\end{array}$ & $\begin{array}{c}\mathrm{Al}_{\max } \\
(\mathrm{Amp})\end{array}$ & $\begin{array}{c}\mathrm{Al}_{\min } \\
(\mathrm{Amp})\end{array}$ & $\begin{array}{c}P_{\max } \\
(\mathrm{kbar})\end{array}$ & $\begin{array}{c}P_{\min } \\
(\mathrm{kbar})\end{array}$ & $\begin{array}{c}T_{\max } \\
\left({ }^{\circ} \mathrm{C}\right)\end{array}$ & $\begin{array}{c}T_{\min } \\
\left({ }^{\circ} \mathrm{C}\right)\end{array}$ & $\begin{array}{c}T-P(\mathrm{avg}) \\
\left({ }^{\circ} \mathrm{C} / \mathrm{kbar}\right)\end{array}$ \\
\hline $252 / 2$ & 0.36 & 0.31 & 1.88 & 1.68 & 5.5 & 4.5 & 722 & 668 & $694 / 5.0$ \\
$574 \mathrm{~A}$ & 0.35 & 0.32 & 1.81 & 1.62 & 5.4 & 4.3 & 728 & 674 \\
$123 \mathrm{~A}$ & 0.29 & 0.30 & 1.72 & 1.50 & 4.3 & 3.8 & 738 & $703 / 4.8$ \\
4013 & 0.44 & 0.40 & 1.72 & 1.60 & 5.0 & 4.0 & 739 & 690 \\
$581 \mathrm{~A}$ & 0.35 & 0.32 & 1.53 & 1.41 & 4.1 & 3.5 & 728 & 656 & $707 / 4.1$ \\
\hline
\end{tabular}

Notes: Mole fraction anorthite in magmatic plagioclase, total Alt (p.f.u). in magmatic amphibole, and calculated value of pressure and temperature.

TABLE 2. Amphibole Microprobe analyses of Ca-amphibole

\begin{tabular}{|c|c|c|c|c|c|c|c|c|}
\hline Sample* $^{*}$ & 252 & 252 & $574 \mathrm{~A}$ & $574 \mathrm{~A}$ & $581 \mathrm{~A}$ & $581 \mathrm{~A}$ & $123 \mathrm{~A}$ & $123 \mathrm{~A}$ \\
\hline $\mathrm{SiO}_{2}$ & 43.17 & 43.68 & 43.87 & 44.01 & 45.37 & 45.46 & 44.66 & 44.95 \\
\hline $\mathrm{TiO}_{2}$ & 1.34 & 1.22 & 1.89 & 1.70 & 1.14 & 1.25 & 1.57 & 1.63 \\
\hline $\mathrm{Al}_{2} \mathrm{O}_{3}$ & 9.89 & 10.04 & 9.82 & 9.50 & 8.48 & 8.63 & 8.75 & 8.88 \\
\hline $\mathrm{Cr}_{2} \mathrm{O}_{3}$ & 0.02 & 0.04 & 0.00 & 0.00 & 0.06 & 0.00 & n.d. & n.d. \\
\hline $\mathrm{Fe}_{2} \mathrm{O}_{3}$ & 2.67 & 3.47 & 2.06 & 3.97 & 3.96 & 4.20 & 1.95 & 1.42 \\
\hline $\mathrm{FeO}$ & 16.28 & 15.49 & 15.53 & 14.22 & 13.04 & 12.70 & 15.75 & 15.74 \\
\hline $\mathrm{MnO}$ & 0.38 & 0.52 & 0.31 & 0.27 & 0.47 & 0.59 & 0.47 & 0.49 \\
\hline $\mathrm{MgO}$ & 9.20 & 9.45 & 10.05 & 9.94 & 11.16 & 11.24 & 10.56 & 10.59 \\
\hline $\mathrm{CaO}$ & 11.86 & 11.91 & 11.93 & 11.58 & 11.70 & 11.61 & 11.77 & 11.77 \\
\hline $\mathrm{Na}_{2} \mathrm{O}$ & 1.24 & 1.19 & 1.21 & 1.01 & 1.23 & 1.26 & 1.11 & 1.05 \\
\hline $\mathrm{K}_{2} \mathrm{O}$ & 1.31 & 1.29 & 1.32 & 1.12 & 0.96 & 1.06 & 1.17 & 1.10 \\
\hline$F$ & - & - & - & - & 0.27 & 0.26 & n.d. & n.d. \\
\hline Total & 97.36 & 98.31 & 98.00 & 97.32 & 97.85 & 98.25 & 97.75 & 97.61 \\
\hline $\mathrm{O}=\mathrm{F}$ & - & - & - & - & 0.11 & 0.11 & n.d. & n.d. \\
\hline \multicolumn{9}{|c|}{ Formula proportions of cations based on 230 atoms $\dagger$} \\
\hline $\mathrm{Si}$ & 6.56 & 6.56 & 6.58 & 6.62 & 6.76 & 6.75 & 6.71 & 6.74 \\
\hline $\mathrm{Al}^{\text {tot }}$ & 1.77 & 1.78 & 1.74 & 1.68 & 1.49 & 1.51 & 1.55 & 1.57 \\
\hline $\mathrm{Ti}$ & 0.15 & 0.14 & 0.21 & 0.19 & 0.13 & 0.14 & 0.18 & 0.18 \\
\hline $\mathrm{Cr}$ & 0.00 & 0.01 & - & - & 0.01 & - & n.d. & n.d. \\
\hline $\mathrm{Fe}^{3+}$ & 0.31 & 0.39 & 0.23 & 0.45 & 0.44 & 0.47 & 0.22 & 0.16 \\
\hline $\mathrm{Fe}^{2+}$ & 2.07 & 1.95 & 1.95 & 1.79 & 1.63 & 1.58 & 1.98 & 1.97 \\
\hline $\mathrm{Mn}$ & 0.05 & 0.07 & 0.04 & 0.03 & 0.06 & 0.07 & 0.06 & 0.06 \\
\hline $\mathrm{Mg}$ & 2.08 & 2.12 & 2.25 & 2.23 & 2.48 & 2.49 & 2.36 & 2.37 \\
\hline $\mathrm{Ca}$ & 1.93 & 1.92 & 1.92 & 1.87 & 1.87 & 1.85 & 1.90 & 1.89 \\
\hline $\mathrm{Na}$ & 0.37 & 0.35 & 0.35 & 0.29 & 0.36 & 0.36 & 0.32 & 0.31 \\
\hline K & 0.25 & 0.25 & 0.25 & 0.22 & 0.18 & 0.20 & 0.23 & 0.21 \\
\hline $\mathrm{F}$ & - & - & - & - & 0.13 & 0.12 & n.d. & n.d. \\
\hline
\end{tabular}

* Sample numbers refer to localities in Figure 1.

† $\mathrm{Fe}^{2+} / \mathrm{Fe}^{3+}$ estimation assuming 13 cations.

ence in calculated pressure cannot be interpreted and is probably insignificant. The most important information from the Al-in-hornblende barometry is that the Schlieren granite was formed at midcrustal levels, and no major postmagmatic tilting of the Mühlzone (and the magmatic shear structures) occurred during exhumation. It is plausible that increased undercooling of the melt and/or decreasing melt content changed the rheological behavior of the magma. Changing rheological properties may have caused the activation of submagmatic reverse shear zones, which included plastic deformation of feldspar. Some of the zones are parallel to the steepest S2 planes, but most of them are steeper and dip to the north or are parallel to the D3 shear-zone system. Shear-plane orientations may have changed successively from the low-angle orientation of D2 towards the steep orientation of D3 during the submagmatic stage. The presence of S-C fabrics in E-W striking submagmatic shear zones (type B) suggest N-S crustal shortening (like the D2 structures). These submagmatic shear zones are rare, suggesting that the $(P-) T-X^{\text {melt/solid }}$ interval where they could be generated was probably small. Strike-slip shear- ing in the D3 shear zones started at $P-T$ conditions similar to those estimated for the solidification of the granites. However, D3 shortening, which was also N-S oriented (Brandmayr et al. 1995) occurred in the solid-state and continued during cooling of the crust to greenschist-facies temperatures. The time span between intrusion of the Weinsberg granite (330-320 Ma, Friedl et al. 1996) and cooling of white micas from D3 shear zones below $\sim 375^{\circ} \mathrm{C}(\sim 288 \mathrm{Ma}$, Brandmayr et al. 1995) indicates a low average crustal cooling rate of $\sim 9{ }^{\circ} \mathrm{C} / \mathrm{m}$.y. This cooling rate is consistent with abundant evidence for recovery and static recrystallization in all investigated rocks (e.g., formation of subgrains, transformation of myrmekites into aggregates of plagioclase and quartz, and static recrystallization of quartz in shear zones).

\section{ACKNOWLEDGMENTS}

This work is a contribution within the research program "Orogene Prozesseihre Quantifizierung und Simulation am Beispiel der Varisziden" funded by the "Deutsche Forschungsgemeinschaft" (DFG grant Kr 691/16 and Bu 990/2-1). Malc Roberts (Rhodes University), Ulrich Riller (Geoforschungszentrum Potsdam), and Gerhard Franz (TU Berlin) supplied valuable comments and 
improved the English text. Scott R. Paterson (University of Southern California), Jörn H. Kruhl (Technische Universität München), and Scott E. Johnson (Macquarie University, Sydney) provided constructive suggestions for improvement in their reviews.

\section{REFERENCES CITED}

Altenberger, U., Hamm, N., and Kruhl, J.H. (1987) Movements and metamorphism north of the Insubric Line between Val Loana and Val d'Ossola, N Italy. Jahrbuch der Geologischen Bundesanstalt Wien, 130, 365-374.

Anderson, J.L. and Smith, D.R. (1995) The effects of temperature and $f_{\mathrm{O}_{2}}$ on the Alin-hornblende barometer. American Mineralogist, 80, 548-559.

Arzi, A.A. (1978) Critical phenomena in the rheology of partially melted rocks. Tectonophysics, 44, 173-184.

Benn, K. and Allard, B. (1989) Preferred mineral orientations related to magmatic flow in ophiolite layered gabbros. Journal of Petrology, 30, 925-946.

Blumenfeld, P. and Bouchez, J.L. (1988) Shear criteria in granite and migmatite deformed in the magmatic and solid states. Journal Structural Geology, 10,361372 .

Bouchez, J.L., Delas, C., Gleizes, G., and Nédélec, A. (1992) Submagmatic microfractures in granites. Geology, 20, 35-38.

Brandmayr, M., Dallmeyer, R.D., Handler, R., and Wallbrecher, E. (1995) Conjugate shear zones in the southern Bohemian Massif (Austria): implications for Variscan and Alpine tectonothermal activity. Tectonophysics, 248, 97-116.

Büttner, S. and Kruhl, J.H. (1997) The evolution of a late-Variscan high-T/low-P region: the southeastern margin of the Bohemian Massif. Geologische Rundschau, 86, 21-38.

Davidson, C., Rosenberg, C., and Schmid, S.M. (1996) Synmagmatic folding of the base of the Bergell pluton, Central Alps. Tectonophysics, 265, 213-238.

Elwell, D. and Scheel, H.J. (1975) Crystal growth from high-temperature solutions. 634 p. Academic Press, London.

Finger, F. (1986) Die synorogenen Granitoide und Gneise des Moldanubikums im Gebiet der Donauschlingen bei Obermühl (Oberösterreich). Jahrbuch der Geologischen Bundesanstalt, 128, 383-402.

Finger, F. and Clemens, J.D. (1995) Migmatization and "secondary" granitic magmas: effects of emplacement and crystallization of "primary" granitoids in Southern Bohemia, Austria. Contributions to Mineralogy and Petrology, 120, 311326.

Franke, W. (1989) Tectonostratigraphic units in the Variscan belt of central Europe. In R.D. Dallmeyer, Ed., Terranes in the Circum-Atlantic Paleozoic Orogens, p. 67-90. Geological Society of America Special Publication 230.

Frasl, G., Fuchs, G., Kurzweil, H., Thiele, O., Vohryzaka, K., and Zirkl, E. (1965) Übersichtskarte des Kristallins im westlichen Mühlviertel und im Sauwald, Öberösterreich. Maßstab 1: 100.000. Geologische Bundesanstalt Wien.

Friedl, G., von Quadt, A., Frasl, G., and Finger, F. (1992) Neue U/Pb Altersdaten aus der südlichen Böhmischen Masse. Frankfurter Geowissenschaftliche Arbeiten Serie A, 11, 217-218.

Friedl, G., von Quadt, A., Ochsner, A., and Finger, F. (1993) Timing of the Variscan orogeny in the South Bohemian Massif (NE Austria) deduced from new U-Pbzircon and monazite dating. Terra Abstracts, 5, 235-236.

Friedl, G., von Quadt, A., and Finger, F. (1996) Timing der Intrusionstätigkeit im Südböhmischen Batholith. TSK 6, Salzburg, Book of Abstracts: 127-130.

Fuchs, G. and Thiele, O. (1965) Erläuterungen zur Übersichtskarte des Kristallins im westlichen Mühlviertel und im Sauwald, Oberösterreich. 95 p. Geologische Bundesanstalt Wien.

Gapais, G. and Barbarin, B. (1986) Quartz fabric transition in a cooling syntectonic granite (Hermitage Massif, France). Tectonophysics, 125, 357-370.

Handler, R., Brandmayr, M., and Wallbrecher, E. (1991) The Rodl Shear Zone in the southern Bohemian Massif. Zentralblatt für Geologie und Paläontologie Teil I. 1, 68-86.

Hoisch, T.D. (1989) A muscovite-biotite geothermometer. American Mineralogist, $74,565-572$.

Holdaway, M.J. (1971) Stability of andalusite and the aluminum silicate phase diagram. American Journal of Science, 271, 97-131.

Holdaway, M.J. and Lee, S.M. (1977) Fe-Mg cordierite stability in high grade pelitic rocks based on experimental, theoretical and natural observations. Contributions to Mineralogy and Petrology, 63, 175-198.

Holland, T.J.B. (1979) Experimental determination of the reaction Paragonite $=\mathrm{Ja}-$ deite + Kyanite $+\mathrm{H}_{2} \mathrm{O}$, and internally consistent thermodynamic data for part of the system $\mathrm{Na}_{2} \mathrm{O}-\mathrm{Al}_{2} \mathrm{O}_{3}-\mathrm{SiO}_{2}-\mathrm{H}_{2} \mathrm{O}$, with application to eclogites and blueschists. Contributions to Mineralogy and Petrology, 68, 292-301.
Holland, T. and Blundy, J. (1994) Non-ideal interactions in calcic amphiboles and their bearing on amphibole-plagioclase thermometry. Contributions to Mineralogy and Petrology, 116, 433-447.

Hutton, D.H.W. (1988a) Granite emplacement and tectonic controls: inferences from deformation studies. Transactions of the Royal Society of Edinburgh, Earth Sciences, 79, 245-255.

(1988b) Igneous emplacement in a shear zone termination: the biotite granite at Strontian, Scotland. Bulletin of the Geological Society of America, 100, 13921399.

Hutton, D.H.W. and Reavy, R.J. (1992) Strike-slip tectonics and granite petrogenesis. Tectonics, 11, 960-967.

Kretz, R. (1983) Symbols for rock-forming minerals. American Mineralogist, 68, 277-279.

Kruhl, J.H. (1996) Prism- and basis-parallel subgrain boundaries in quartz: A microstructural geothermobarometer. Journal of metamorphic Geology, 14, 581598.

(1998) Prism- and basis-parallel subgrain boundaries in quartz: A microstructural geothermobarometer-Reply. Journal of metamorphic Geology, 16, 142146.

Leake, B.E. (1978) Nomenclature of amphiboles. American Mineralogist, 63, $1023-$ 1052.

Masch, L. and Cetin, B. (1991) Gefüge, Deformationsmechanismen und Kinematik in ausgewählten Hochtemperatur-Mylonitzonen im Moldanubikum des Bayerischen Waldes. Geologica Bavarica, 96, 7-27.

Massonne, H.J. and Schreyer, W. (1987) Phengite geobarometry based on the limiting assemblage of potassium feldspar, phlogopite and quartz. Contributions to Mineralogy and Petrology, 96, 212-224.

Miller, R.B. and Paterson, S.R. (1994) The transition from magmatic to high-T solidstate deformation: implications from the Mount Stuart batholith, Washington. Journal of Structural Geology, 16, 853-865.

Nicolas, A. (1992) Kinematic in Magmatic Rocks with Special Reference to Gabbros. Journal of Petrology, 33, 891-915.

Passchier, C.W. and Trouw, R.A.J. (1996) Microtectonics, 289 p. Springer Verlag, Berlin.

Paterson, S.R. and Fowler, T.K. (1993) Extensional pluton emplacement models: Do they work for large plutonic complexes? Geology, 21, 781-784.

Paterson, S.R. and Miller, R.B. (1998) Magma emplacement during arc-perpendicular shortening: An example from the Cascades crystalline core, Washington. Tectonics, 17, 571-586.

Paterson, S.R., Vernon, R.H., and Tobisch, O.T. (1989) A review of criteria for the identification of magmatic and tectonic foliations in granitoids. Journal of Structural Geology, 11, 349-363.

Pitcher, W.S. (1993) The nature and origin of granite, 321 p. Blackie Academic \& Professional, London.

Schmidt, M.W. (1992) Amphibole composition in tonalite as a function of pressure: an experimental calibration of the Al-in-hornblende barometer. Contributions to Mineralogy and Petrology, 110, 304-310.

Spear, F.S. and Cheney, J.T. (1989) A petrogenetic grid for pelitic schists in the system $\mathrm{SiO}_{2}-\mathrm{Al}_{2} \mathrm{O}_{3}-\mathrm{FeO}-\mathrm{MgO}-\mathrm{K}_{2} \mathrm{O}-\mathrm{H}_{2} \mathrm{O}$. Contributions to Mineralogy and Petrology, 101, 149-164.

Sturm, R. (1995) Geologisch-petrographische Bearbeitung eines cordieritführenden Mylonits und seiner Unmrahmung im Bereich des Pfahls, oberösterreichisches Moldanubikum, 155 p. Dipl. Thesis, University of Salzburg.

Tullis, J. and Yund, R.A. (1991) Diffusion creep in feldspar aggregates: experimental evidence. Journal of Structural Geology, 13, 987-1000.

Van der Molen, I. and Paterson, M.S. (1979) Experimental deformation of partiallymelted granite. Contributions to Mineralogy and Petrology, 70, 299-318.

van Groos, A.F.K. and Heege, J.P.T. (1973) The high-low quartz transition up to 10 kilobars pressure. Journal of Geology, 81, 717-724.

Vernon, R.H. (1986) potassium feldspar megacrysts in granites—Phenocrysts, not porphyroblasts. Earth-Science Reviews, 23, 1-63.

Vernon, R.H. and Collins, W.J. (1988) Igneous microstructures in migmatites. Geology, 16, 1126-1129.

Voll, G. (1976) Recrystallization of quartz, biotite, feldspars from Erstfeld to the Leventina Nappe, Swiss Alps, and its geological significance. Schweizer Mineralogische und Petrographische Mitteilungen, 56, 641-647.

MANUSCRIPT RECEIVED OCTOBER 15, 1998

MANUSCRIPT ACCEPTED JUNE 10, 1999

PAPER HANDLED BY SCOTT E. JOHNSON 